ANNA WiLKOSZ

Uniwersytet Śląski, Katowice

\title{
Procesy restrukturyzacji ALSTOM Konstal S.A. w Chorzowie
}

Pojęcie restrukturyzacji, jako termin encyklopedyczny, w literaturze polskiej i zagranicznej pojawiło się dopiero w latach 90. XX w., po ukazaniu się książki M.J. Rocka i R.H. Rocka pt. Corporate Restructuring. A Guide to Creating the Premium - Volued Company [Sapijaszka 1996: 24]. Jednakże już wcześniej, w latach 80. XX w. podejmowano próby definiowania tego pojęcia. A. Leszczyński ,poszukując odpowiedzi na pytanie, na czym polega restrukturyzacja gospodarki, dowodził, że chodzi o stopniowe przekształcenia w zakresie rozmiarów i proporcji produkcji, metod wytwarzania, układów własnościowych i systemów zarządzania" [Tkocz 2001: 27].

A. Karpiński [1986: 20] natomiast utożsamiał procesy restrukturyzacji

ze zmianami strukturalnymi w bazie materialnej społeczeństwa, które prowadzą do zwiększenia roli wszystkich tych elementów tej struktury, które reprezentują nowoczesność i z reguły wyższą efektywność od rozwiązań dotychczasowych. Towarzyszą temu najczęściej bardziej efektywne rozwiązania w sferze systemu funkcjonowania gospodarki, korzystniejsze relacje między nakładami a wynikami gospodarczymi, a w rezultacie postęp w zaspokajaniu potrzeb ludzkich w kierunku rozwiązań bardziej niż dotąd racjonalnych i skutecznych.

Podobnie restrukturyzację definiuje S. Misztal. Pod tym pojęciem rozumie on „świadoma, długofalową akcję państwa lub organizacji gospodarczych, zmierzającą do zasadniczych przekształceń dotychczasowych struktur społeczno-ekonomicznych" [Tkocz 2001: 28]. Głównym jej celem jest unowocześnienie i zwiększenie efektywności gospodarki narodowej.

Natomiast według A. Klasika [1988: 89] restrukturyzacja to

proces ciagły, obejmujący jednocześnie odnawianie ukształtowanej struktury obiektu oraz jej przebudowę. Odnawianie dotyczy tej części struktury obiektu, na którą składają się wartościowe elementy tradycji kulturowej, w tym tradycji technicznej i wytwórczej. Przebudowa odnosi się natomiast do pozostałej części struktury obiektu, która ze względu na cele jego podmiotu i warunki otoczenia ulega likwidacji, przekształceniu bądź zastapieniu przez nowe elementy.

Obecnie w polskiej literaturze ekonomicznej restrukturyzacja definiowana jest na podstawie procesów jakie zachodzą w gospodarce. Według B. Pełki [1992: 84] jest to „zmiana struktury produkcyjnej i organizacyjnej przedsiębiorstwa w odniesieniu do techniki, technologii, form organizacji produkcji i systemu zarządzania oraz jego statusu organizacyjno-prawnego”. Polega ona na „sprzedaży części firmy, pozyskaniu nowych dziedzin działalno- 
ści, zmianie struktury kapitałowej poprzez zwiększenie poziomu zadłużenia, prywatyzację czy zmianę wewnętrznej organizacji firmy" [Sapijaszka 1996: 26].

Natomiast przez zagranicznych badaczy, takich jak Bicksler, Chen, Myers, Hoskinsson czy Turk, restrukturyzacja określana jest jako strategia wzrostu wartości firmy, która zachodzi na trzech poziomach: aktywów, struktury kapitałowej i zarządzania.

Restrukturyzacja w literaturze definiowana jest w odniesieniu do różnego rodzaju kryteriów. A. Karpiński [1986] wyróżnia dwa rodzaje restrukturyzacji, w zależności od zasięgu jej oddziaływania. Jest to restrukturyzacja w skali mikro i w skali makro.

Mikrorestrukturyzacja „dokonuje się bezpośrednio w jednostkach produkcyjnych gospodarki i polega na zmianie w asortymencie bądź profilu produkcyjnym przedsiębiorstwa" [Tkocz 2001: 33]. Natomiast makrorestrukturyzacja zachodzi w skali gospodarki narodowej.

W pojęciu tym zawarty jest proces, w którym państwo za pomocą różnych środków aktywnie działa w kierunku przyspieszenia rozwoju produkcji jednych wyrobów, grup wyrobów czy gałęzi przemysłu lub gospodarki kosztem innych, zmierzając w ten sposób do poprawy ekonomicznych wyników. Towarzyszą temu na ogół zmiany w przeznaczeniu środków kierowanych na rozwój, zwłaszcza środków inwestycyjnych, z gałęzi tradycyjnych do tych, które dzisiaj odgrywają kluczową rolę we współczesnym postępie naukowo-technicznym [Tkocz 2001: 33].

W przemyśle restrukturyzacja zachodzi na ogół w skali mikro. „Według B. Pełki oznacza ona zmiany struktury produkcji przemysłowej, systemu zarządzania przemysłem oraz statusu prawno-organizacyjnego poszczególnych sektorów i przedsiębiorstw przemysłowych" [Tkocz 2001: 35]. W. Jakóbik [1993: 6] pod pojęciem restrukturyzacji przemysłu rozumie natomiast „odnowienie dotychczasowej struktury produkcji, która okazała się technicznie przestarzałą lub/i nie odpowiadającą aktualnej strukturze popytu".

Restrukturyzacja przemysłu może mieć charakter:

- przedmiotowy,

- podmiotowy,

- naprawczy,

- rozwojowy [Janczewska, Zdżyłowski 1997].

Restrukturyzacja przedmiotowa polega na zmianie sposobu funkcjonowania przedsiębiorstwa w wyniku zmian technologii i sposobu produkcji. Restrukturyzacja podmiotowa natomiast - na zmianach własnościowych i organizacyjnych przedsiębiorstwa [Sobczyk 1997].

Restrukturyzacja naprawcza prowadzi do poprawy sytuacji ekonomiczno-finansowej przedsiębiorstwa poprzez restrukturyzację finansów i zatrudnienia [Kowalczuk-Jakubowska, Malewicz 1992]. Ostatnim typem restrukturyzacji przemysłu jest restrukturyzacja rozwojowa, czyli ,rozmaite działania prowadzące do przełomu innowacyjnego, a jednocześnie próba realizacji niektórych założeń planu strategicznego przedsiębiorstwa w zakresie strategii technologicznej, ekonomicznej i marketingowej” [Tkocz 2001: 37].

Ponadto wyróżnić możemy restrukturyzację produktową, polegającą na podnoszeniu wartości rynkowej produktów, wydajności i nowoczesności procesów wytwórczych oraz obniżeniu kosztów własnych produkcji [Skowronek, Sobczyk, Zdżyłowski 1997], restrukturyzację technologiczną, polegającą na wprowadzaniu nowych maszyn i urządzeń oraz wdrażaniu nowych technologii do procesu produkcji [Skowronek, Sobczyk, Zdżyłowski 1997], restrukturyzację organizacyjną, która polega na przystosowaniu przedsiębiorstwa do działań w środowisku rynkowym poprzez zmiany w strukturach organizacyjnych przedsiębiorstw [Mikołajewicz 1995] oraz restrukturyzację przestrzenną, czyli „sterowanie procesami roz- 
woju społeczno-gospodarczego w celu racjonalnego zagospodarowania i użytkowania przestrzeni [Tkocz 2001: 38].

W przypadku ALSTOM Konstal S.A. w Chorzowie restrukturyzacja zachodziła w dwóch etapach:

- prywatyzacja i wykup firmy przez koncern ALSTOM,

- zmiana wewnętrznej organizacji mająca na celu dostosowanie do nowych technologii i technik produkcji.

\section{Geneza powstania ALStOM Konstal S.A. w Chorzowie}

Powstanie Konstalu, a następnie jego przekształcenie w ALSTOM Konstal S.A. w Chorzowie zapoczątkowane zostało w latach 30. XIX w. budową wydziału Alvenslebenhütte I, a następnie w latach 50. i 60. XIX w. - budową wydziału Alvenslebenhütte II. W wydziałach tych produkowano przede wszystkim wyroby gotowe (szyny kolejowe, obręcze, blachy, kształtowniki, taśmy płaskie, żelazo prętowe i rafinowane). W 1864 r. przekształcono oba wydziały w tzw. Warsztaty Przetwórcze, czyli „kompleks zabudowań fabrycznych wyposażonych w nowoczesne urządzenia i maszyny" [Karpiński, Soida 1999: 14], produkujące przede wszystkim na potrzeby transportu szynowego.

Jedną z bezpośrednich przyczyn utworzenia w Hucie Królewskiej Warsztatów Przetwórczych była rozbudowa kolei żelaznej na Śląsku w latach 60 . XIX w. oraz zwiększające się możliwości przewozu wytwarzanych artykułów przemysłowych nie tylko do okolicznych zakładów. Dzięki uruchomieniu własnego wydziału przetwórczego zwiększyły się możliwości konkurencyjne Huty Królewskiej w porównaniu z innymi zakładami w zakresie przetwórstwa stali, co zatem zapewniło hucie dodatkowe zyski [Chorzowska wytwórnia..., 1964: 5].

W 1869 r., ze względu na słabą kondycję finansową, Huta Królewska wraz z Warsztatami Przetwórczymi oraz kopalniami rud i wapienia została sprzedana hrabiemu Hugo Henkelowi von Donersmarkowi. Z jego inicjatywy w 1871 r. utworzono w Berlinie spółkę akcyjna „Zjednoczone Huty Królewska i Laura”. W kolejnych latach (1871-1908) przeprowadzono generalną modernizację Warsztatów Przetwórczych finansowaną przez państwo pruskie. Uruchomiono wówczas sześć oddziałów: Zestawów Kołowych, Budowy Mostów, Budowy Wagonów, Tłoczni, Rozjazdów Kolejowych oraz Resorów i Sprężyn.

Po I wojnie światowej, na podstawie przeprowadzonego plebiscytu i podpisanej w $1922 \mathrm{r}$. w Genewie Polsko-Niemieckiej Konwencji Górnośląskiej, Chorzów wraz z Warsztatami Przetwórczymi został włączony do Polski. Miało to niekorzystne skutki dla fabryki, związane z ograniczeniem niemieckiego rynku zbytu. „W 1926 r. berlińskie towarzystwo Zjednoczone Huty Królewska i Laura utworzyło spółkę filialną w Katowicach pod nazwą Górnośląskie Zjednoczone Huty Królewska i Laura, Spółka Akcyjna Górniczo-Hutnicza" [Karpiński, Soida 1999: 27], która przejęła zakłady macierzystego koncernu znajdujące się na terenie Polski, a od 1929 r. działała pod nazwą Wspólnota Interesów Górniczo-Hutniczych. W tym czasie, aż do wybuchu II wojny światowej zajmowano się produkcją konstrukcji stalowych i mostów oraz na niewielką skalę rozpoczęto produkcję wagonów tramwajowych, których głównym odbiorcą były miasta: Katowice, Sosnowiec i Warszawa.

Po rozpoczęciu II wojny światowej w 1939 r. majątek Wspólnoty Interesów Górniczo-Hutniczych przeszedł pod zarząd niemieckiego koncernu Reichswerke A.G. für Berg- 
und Hüttenbetrieben Herman Göring. „Dla administrowania zakładami na Górnym Śląsku koncern ten utworzył 1 kwietnia 1940 r. przedsiębiorstwo filialne w Katowicach o nazwie Bergwerksverwaltung Oberschlesien G.m.b.H. der Reichswerke Herman Göring" [Karpiński, Soida 1999: 41]. W fabryce produkowano wówczas elementy zbrojeniowe, głównie szkielety okrętów podwodnych, suchych doków, podwozi do dział polowych i przeciwlotniczych. Ponadto nadal produkowano lokomotywy tramwajowe do Katowic i Berlina oraz konstrukcje stalowe.

Po wyzwoleniu Chorzowa w 1945 r. podjęto próbę odbudowy Warsztatów Przetwórczych zmieniając nazwę zakładu na Chorzowska Wytwórnia Wagonów i Mostów (MOSTWAGON). Wytwórnia zajmowała się przede wszystkim odbudową zniszczonych wojną konstrukcji mostowych i stalowych głównie w Płocku, Warszawie, Kielcach, Krakowie, Toruniu i Wrocławiu. Ponadto od 1946 r. rozpoczęła masową produkcję tramwajów (głównie dla Berlina, Grodziska Mazowieckiego i Katowic), wagonów kolejowych, węglarek i wózków dołowych. W 1949 r. rozpoczęto produkcję taboru kolejowego na eksport, głównie do Bułgarii. W tym także roku zmieniono nazwę zakładu na Chorzowska Wytwórnia Konstrukcji Stalowych. Rozpoczęto produkcję lokomotyw dołowych, zwiększono produkcję elementów tłoczonych, sprężyn i zderzaków tak, iż Chorzowska Wytwórnia Konstrukcji Stalowych stała się największym dostawcą tego asortymentu w kraju.

W latach 50. XX w. poczyniono kolejne inwestycje i wykonano prace modernizacyjne, które przyczyniły się do dalszych sukcesów chorzowskiego przedsiębiorstwa (głównie produkcja na eksport do Bułgarii, Rumunii i Mozambiku). Na szeroką skalę rozpoczęto produkcję wagonów tramwajowych różnego typu. Ponadto zajmowano się produkcją konstrukcji stalowych i mostowych, ale w mniejszej skali. Od początku lat 60 . XX w. wykonywano coraz mniejszą liczbę dużych konstrukcji mostowych, ze względu na ograniczenie popytu na tego typu budowle. Produkowano przede wszystkim na eksport. Głównymi odbiorcami tych produktów były: Czechosłowacja, ZSRR, NRD, Bułgaria, Rumunia, Albania, Hiszpania, Kanada, Indie, Chiny, Irak, Wietnam, Kazachstan i Boliwia.

W latach 1975-1985 Konstal podjął współpracę z amerykańską firmą NORCA Machinery Company Ltd., efektem której była budowa czterech platform wiertniczych dla energetyki krajowej i odbiorcy tureckiego.

W 1994 r. Konstal podpisał akt notarialny przekształcający przedsiębiorstwo państwowe Chorzowska Wytwórnia Konstrukcji Stalowych Konstal w jednoosobową spółkę Skarbu Państwa o nazwie Konstal S.A. W tym także roku Konstal podpisał kontrakt na produkcję 580 podwozi do wagonów towarowych z niemieckim zakładem Linke-Hoffman-Busch G.m.b.H. należącym do koncernu GEC ALSTHOM, który w 1995 r. podjął decyzję o przejęciu 98\% akcji Konstalu. Umowę sprzedaży akcji Konstalu sfinalizowano 27 lutego 1997 r., a w 1998 r. koncern GEC ALSTHOM wszedł na giełdę zmieniając nazwę na ALSTOM.

\section{Dzialalność ALSTOM Konstal S.A. w Chorzowie}

ALSTOM Konstal S.A. w Chorzowie jest jedną z siedmiu filii francusko-brytyjskiego koncernu GEC ALSTOM, działającego na polskim rynku. Macierzysty koncern powstał w 1989 r. jako spółka joint venture firm General Electric Corporation i Alcatel Alsthom. Działa obecnie w 70 krajach, gdzie zatrudnia około 76800 pracowników. Koncern specjali- 
zuje się przede wszystkim w dziedzinie infrastruktury energetycznej (66\%) i transportowej (28\%) oraz w przemyśle i budownictwie okrętowym (6\%). Swoje produkty dostarcza na wszystkie rynki świata (ryc. 1). Największymi odbiorcami artykułów produkowanych przez firmy należące do koncernu, są państwa europejskie (50\% produkcji) oraz kraje azjatyckie położone w rejonie Pacyfiku (19\% produkcji).
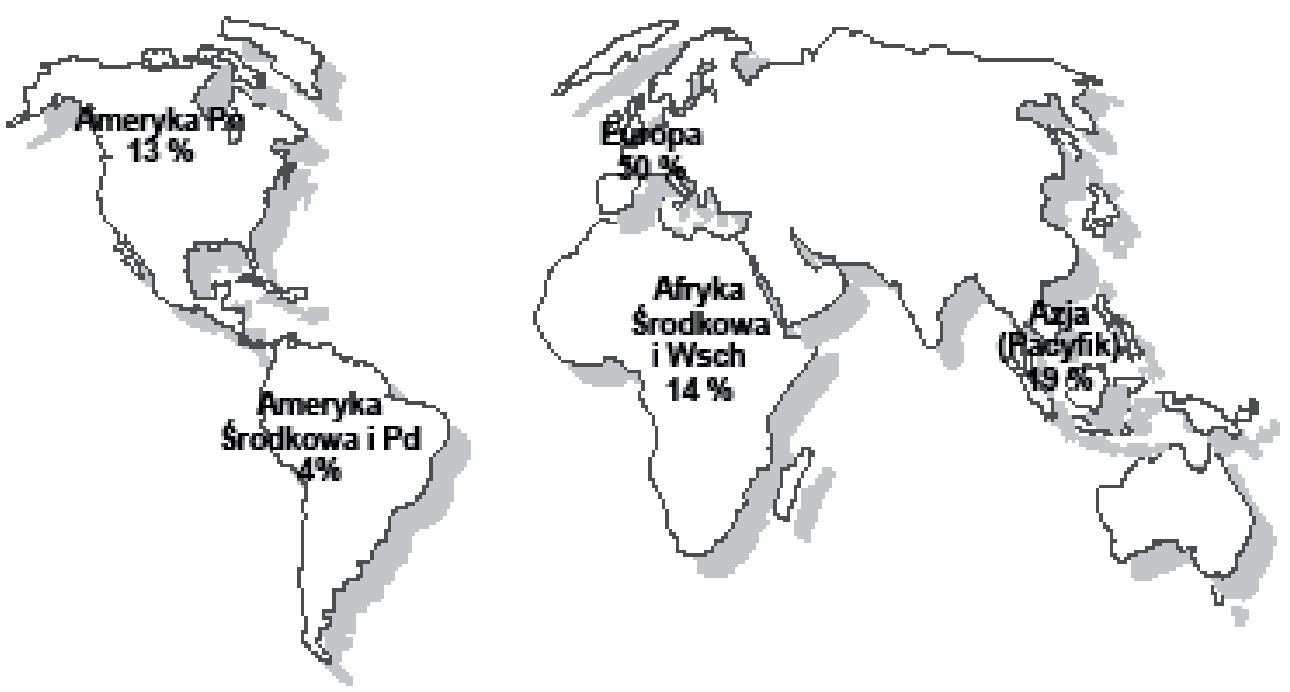

Ryc. 1. Struktura zamówień koncernu GEC ALSTOM na świecie

Źródło: opracowanie własne na podstawie danych z www.alstom.com

W Polsce ALSTOM tworzą spółki, których łączna wartość zamówień sięga $500 \mathrm{mln}$ euro. Spółki te zatrudniają około 3,5 mln osób. Są to (ryc. 2):

- ALSTOM Power Spółka z o.o. z siedzibą w Elblągu, Wrocławiu i Warszawie, zajmująca się produkcją turbin parowych i gazowych, generatorów oraz odlewów turbinowych i okrętowych;

- ALSTOM Power Flow System Spółka z o.o. z siedzibą w Elblągu i Żorach, produkująca systemy rur preizolowanych dla ciepłownictwa oraz dostarczająca oporządzenia do przesyłu i rozdziału energii;

- ALSTOM Konstal S.A. z siedzibą w Chorzowie, która zajmuje się produkcją pojazdów szynowych.

ALSTOM Konstal S.A. działa na polskim rynku od 1997 r. Zajmuje się produkcją wagonów tramwajowych, wagonów metra, wagonów silnikowych, autobusów szynowych i zespołów trakcyjnych dla dużych szybkości oraz wagonów towarowych. Artykuły te produkowane są na potrzeby trzech dużych miast: Katowic, Gdańska i Warszawy oraz do krajów Europy Zachodniej, głównie do Niemiec. 
Ograniczenie w zapotrzebowaniu polskiego rynku na produkty pochodzące z Konstalu związane jest przede wszystkim z panującą w gospodarce krajowej i światowej polityką konkurencji. W latach 50. XX w. ówczesna Chorzowska Wytwórnia Konstrukcji Stalowych była wiodącym dostawcą wagonów tramwajowych, kolejowych oraz konstrukcji stalowych i mostowych w kraju. W swe produkty zaopatrywała większość dużych miast Polski Północnej, Środkowej i Południowej (ryc. 3a). W latach 60. XX w. wraz ze zmniejszeniem produkcji wielkich konstrukcji mostowych oraz nastawieniem fabryki na produkcję eksportowa, ograniczono produkcję na rynek krajowy. Chorzowska Wytwórnia Konstrukcji Stalowych produkowała wówczas jedynie na potrzeby kilku miast: Wrocławia, Poznania, Gdańska, Warszawy i Krakowa (ryc. 3b).

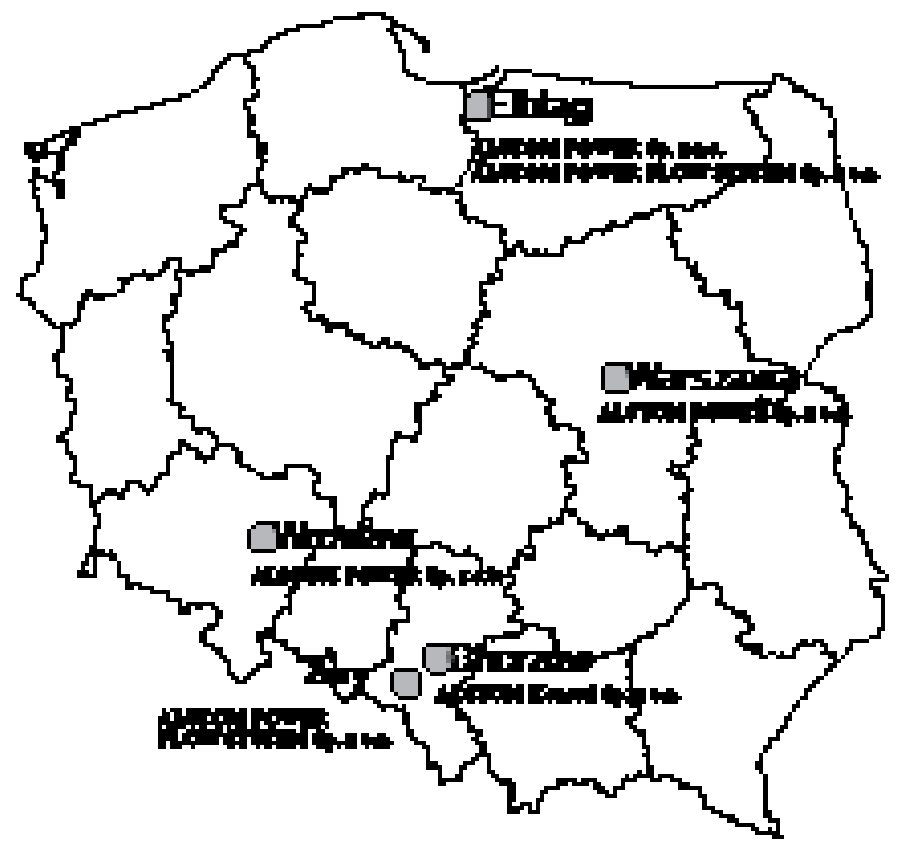

Ryc. 2. Lokalizacja spółek koncernu GEC ALSTOM w Polsce

Źródło: opracowanie własne na podstawie danych z www.alstom.com

W latach 70. i 80. XX w. na szeroką skalę rozpoczęto produkcję wagonów tramwajowych. W tym okresie państwowa firma Chorzowska Wytwórnia Konstrukcji Stalowych, ze względu na politykę panującą w kraju, produkowała tylko na rynek polski (ryc. 3c), a obecnie ze względu na wyspecjalizowanie się firmy w produkcji określonych typów wagonów obszar oddziaływania Konstalu został ograniczony jeszcze bardziej (ryc. 3d). 
a) 1950

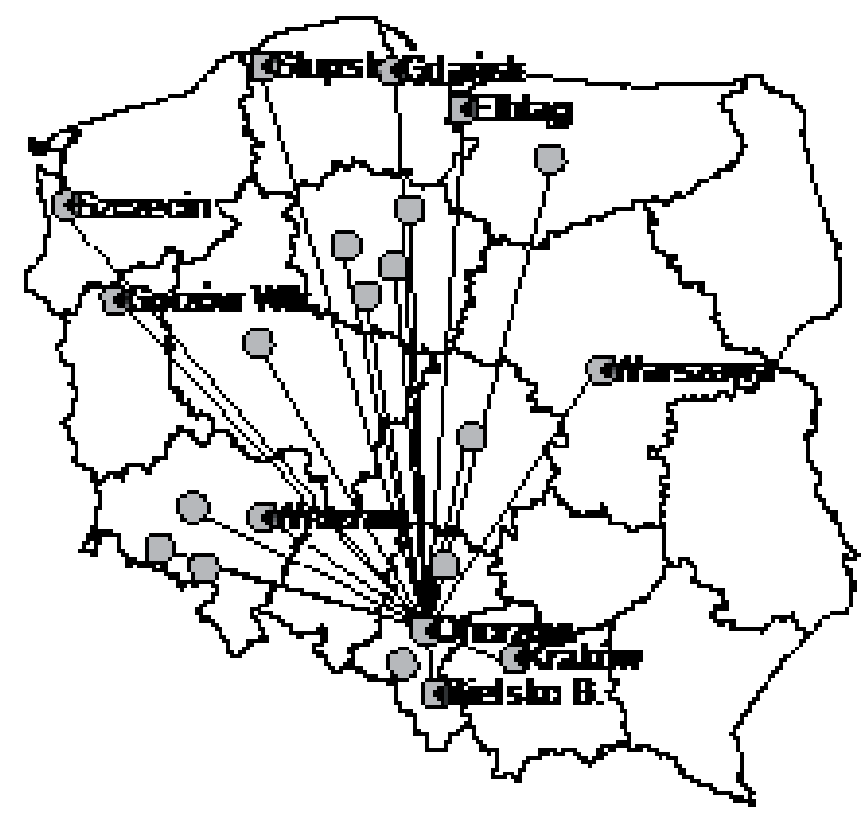

b) $1960-1970$

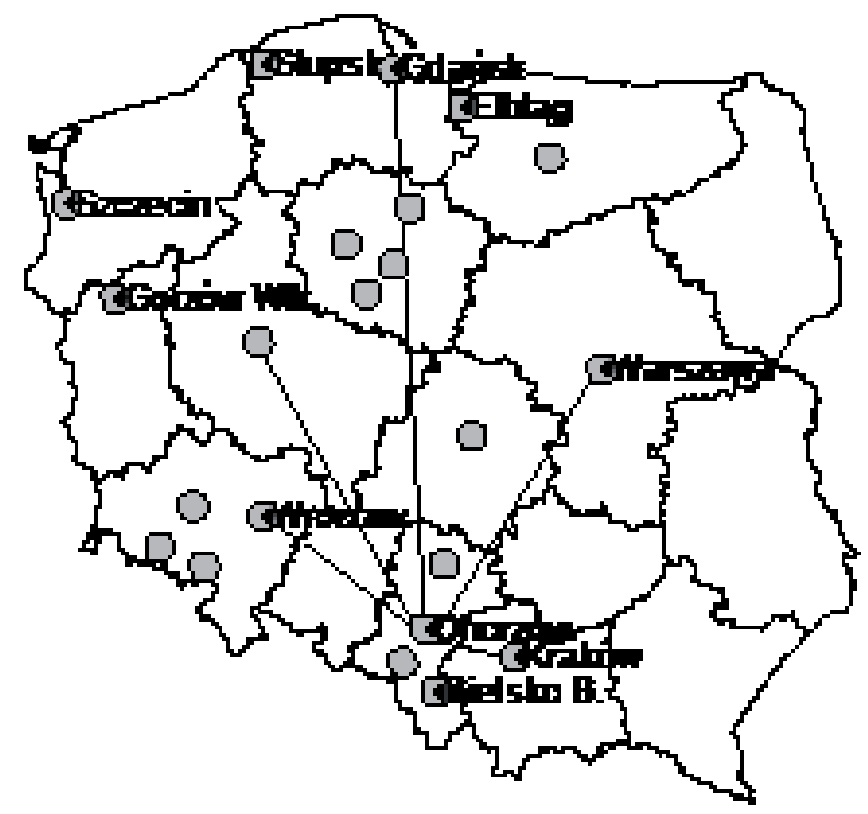


c) 1980

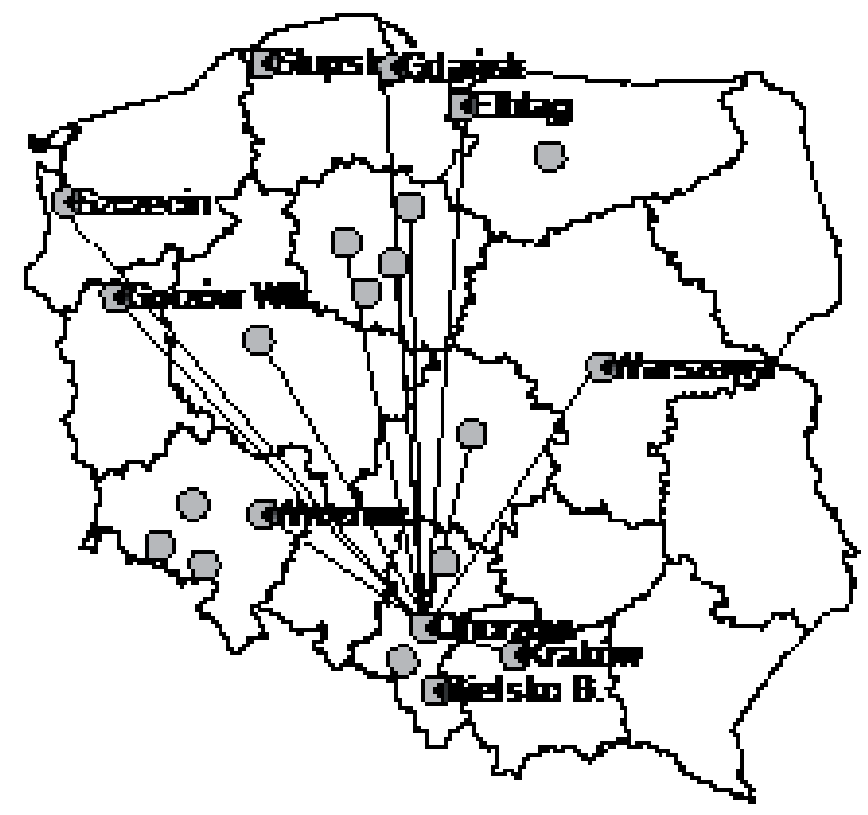

d) po 1998

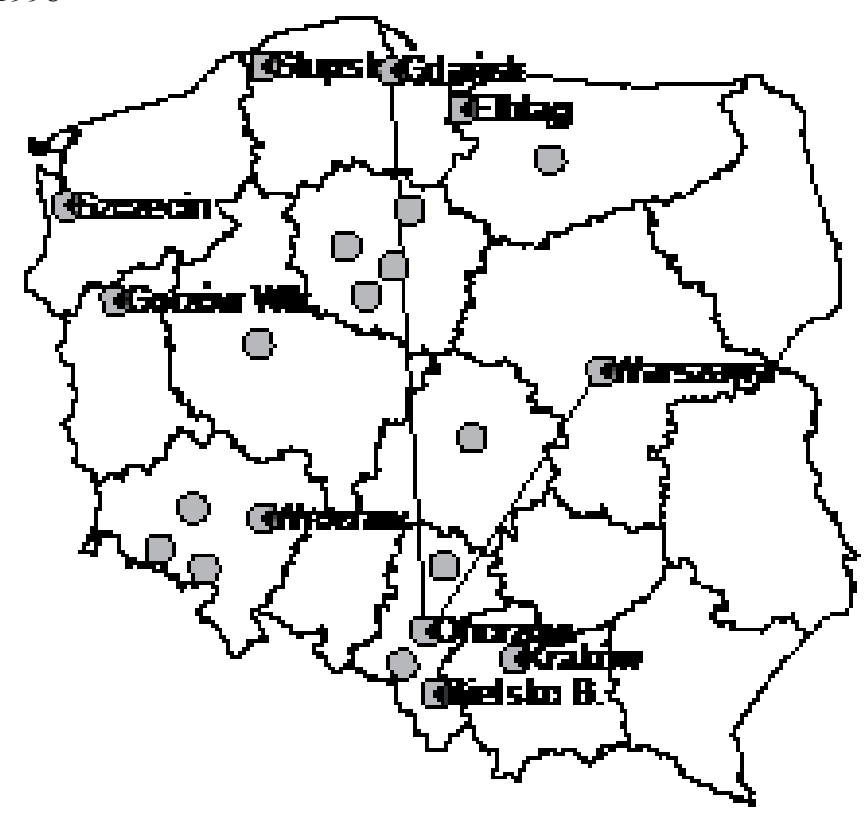

Ryc. 3. Zasięg oddziaływania ALSTOM Konstal S.A. w Polsce w latach 1950-2000 Źródło: opracowanie własne 


\section{InWESTYCJE w ALSTOM Konstal S.A.}

Procesy restrukturyzacji ALSTOM Konstal S.A. w Chorzowie polegały przede wszystkim na modernizacji zakładu oraz wdrażaniu nowych technologii i szkoleniu kadry. W tym celu w latach 1997-2003 koncern GEC ALSTOM zainwestował w Konstalu prawie 28 mln euro (ryc. 4). Największych inwestycji dokonano w pierwszym okresie działalności ALSTOM Konstal S.A., w latach 1997-1999. Wówczas na restrukturyzację zakładu wydano około 20 mln euro. Pieniądze te przeznaczono przede wszystkim na prace remontowe i modernizacyjne, zakup nowoczesnych maszyn, budowę nowych hal i linii produkcyjnych oraz na komputeryzację i kapitał ludzki.

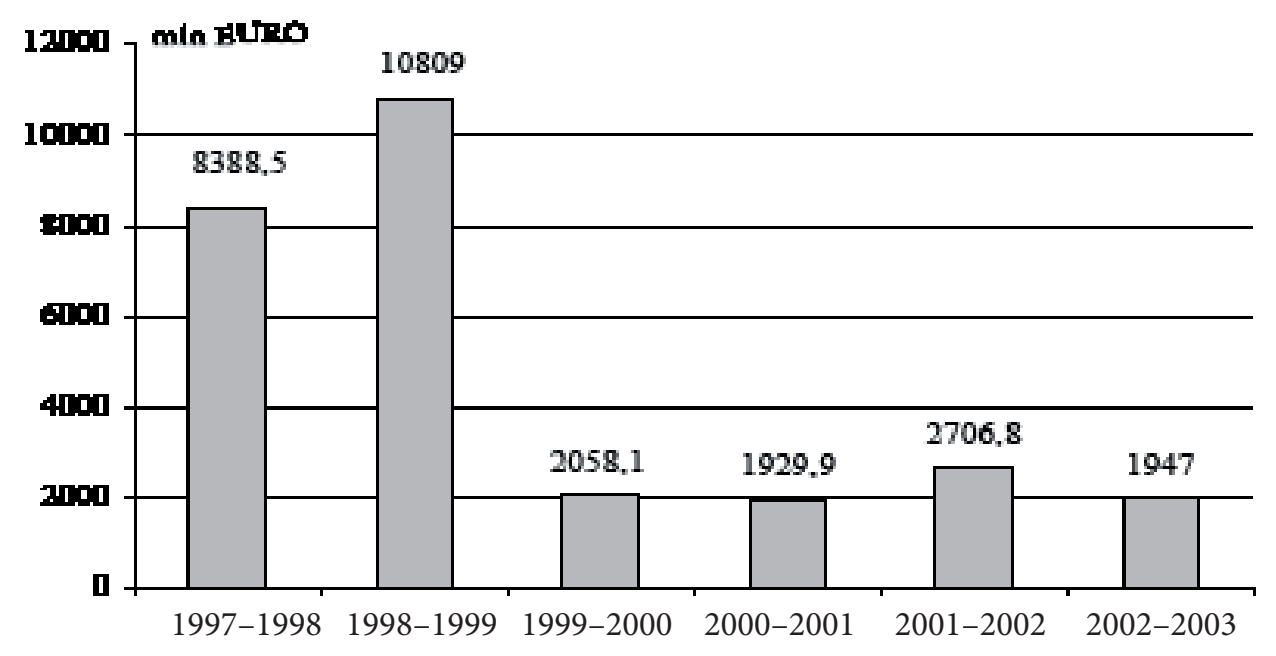

Ryc. 4. Kapitał zainwestowany przez koncern GEC ALSTOM w ALSTOM Konstal S.A. w latach 1997-2003

Źródło: opracowanie własne na podstawie danych z www.alstom.com

W marcu 1997 r. uruchomiono Wydział Zbiorników i Cystern. Z Niemiec sprowadzono oprzyrządowanie do produkcji wagonów węglarek. [...] Na przełomie 1997 r. i 1998 r. oddano do użytku śrutownicę, natomiast w 1998 r. nowoczesną linię lakierniczą. Od podstaw stworzono nową halę $\mathrm{nr} 10$. Wyremontowano $40 \%$ powierzchni pokryć dachowych i drogi zakładowe [Karpiński, Soida 1999: 54].

Po roku 1999 poziom inwestycji znacznie się zmniejszył. Związane jest to przede wszystkim z ukierunkowaniem inwestycji na wdrażanie nowych technologii oraz intensywne szkolenie kadry.

Procesy restrukturyzacji polegające przede wszystkim na wdrażaniu nowych technologii w zakresie projektowania i wytwarzania pojazdów szynowych oraz wieloletnie doświadczenie firmy w produkcji wagonów tramwajowych pozwoliły na osiagnięcie wielu sukcesów w dziedzinie projektowania i produkcji taboru szynowego. W ostatnich latach skonstruowano i wyprodukowano wagony samowyładowcze typu Falns 121 i Faals 151 oraz cztero- 
osiowe cysterny typów 451R i 450R, a także podjęto produkcję pojazdów tramwajowych nowej generacji $(112 \mathrm{~N}, 114 \mathrm{~N}, 116 \mathrm{~N})$. Ponadto Konstal wygrał 5 z 6 przetargów, w których brał udział. Do najważniejszych należy modernizacja linii tramwajowej Katowice-BytomChorzów (w ramach kontraktu Konstal miał dostarczyć 17 nowoczesnych tramwajów) oraz dostawa 108 wagonów dla metra w Warszawie o wartości około 150 mld USD.

$$
* * *
$$

Procesy restrukturyzacji ALSTOM Konstal S.A. w Chorzowie przeprowadzane były etapowo. W pierwszej kolejności dokonano zmian organizacyjnych zakładu, w ramach których zmniejszono liczbę zatrudnionych z około 2800 osób w latach 80 . XX w. do około 900 osób pod koniec lat 90. Kolejnym etapem przemian zainicjowanych w Konstalu była restrukturyzacja przedmiotowa polegająca na zmianie technologii i sposobu produkcji. Pozwoliła ona na dostosowanie produkcji Konstalu do wymogów rynku krajowego i światowego, dzięki czemu przedsiębiorstwo to stało się jedną z najlepszych firm taborowych świata obok Linke-Hoffman-Busch czy Aytre-La Roschelle.

\section{Literatura}

Chorzowska Wytwórnia Konstrukcji Stalowych Konstal 1864-1964, 1964, Chorzów

Jakóbik W. 1993, Restrukturyzacja przemystu w okresie transformacji, Fundacja im. F. Eberta, Warszawa

Janczewska B., Zdżyłowski A. 1997, Procesy restrukturyzacyjne w wybranych przedsiębiorstwach, [w:] Restrukturyzacja przedsiębiorstw i jej wptyw na efektywność gospodarowania, Wydawnictwo UMCS, Lublin, s. 66-79

Karpiński A. 1986, Restrukturyzacja gospodarki w Polsce i na świecie, PWE, Warszawa

Karpiński J., Soida K. 1999, Od Warsztatów Przetwórczych do ALSTOM Konstal S.A. - 135 lat zakta$d u$, Wydawnictwo EMI-PRESS, Łódź

Klasik A. 1988, Restrukturyzacja regionu katowickiego. Tezy, „Studia nad Ekonomiką Regionu”, t. 18, s. $88-101$

Kowalczuk-Jakubowska P., Malewicz A. 1992, Restrukturyzacja jako technika ratowania i rozwoju przedsiębiorstw, Instytut Organizacji Przemysłu Maszynowego, Warszawa

Leszczyński A. 1984, Trudne stowo: restrukturyzacja, „Trybuna Ludu”, nr 237, s. 3

Lipiński J. (red.) 1989, Chorzowska Wytwórnia Konstrukcji Stalowych Konstal 1864-1989 produkcja i wyroby, Chorzów

Pełka B. 1992, Polityka przemystowa, strategia i restrukturyzacja przedsiębiorstwa, IOMP, Warszawa

Sapijaszka Z. 1996, Restrukturyzacja przedsiębiorstwa: szanse i ograniczenia, PWN, Warszawa

Skowronek C., Sobczyk G., Zdżyłowski A. 1997, Restrukturyzacja przedsiębiorstw-przejawy, wyniki, uwarunkowania finansowe i systemowe, [w:] Restrukturyzacja przedsiębiorstw i jej wptyw na efektywność gospodarowania, Wydawnictwo UMCS, Lublin, s. 16-49

Sobczyk G. 1997, Przeksztatcenia własnościowe przedsiębiorstw, [w:] Restrukturyzacja przedsiębiorstw i jej wpływ na efektywność gospodarowania, Wydawnictwo UMCS, Lublin, s. 50-62

Tkocz M. 2001, Restrukturyzacja przemystu regionu tradycyjnego, Wydawnictwo Uniwersytetu Śląskiego, Katowice

www.alstom.com

www.transport.alstom.com

www.metro.civ.pl 
The restructuring process of the ALSTOM Konstal S.A. in Chorzów

The aim of this paper is to analyse the restructuring of ALSTOM Konstal SA in Chorzów in the period 1997-2003. The reasons for this change fall into two main categories.

Firstly, GEC ALSTOM Concern, which specializes in infrastructure of power generation and power service ( $60 \%$ of production), rail transport ( $28 \%$ of production), industry and naval constructions (6\% of production), purchased Konstal SA in 1997.

These days ALSTOM Konstal SA is one of the best European producers of constructed carriages for trams, rail transit systems, fully automatic systems and metro systems. These products are produced mainly for three big cities in Poland: Katowice, Gdansk and Warsaw, and for the EU countries.

Secondly, the modernization brought new technology and staff training. To this aim, in the period 1997-2003 GEC ALSTOM invested 28 million $€$ in Konstal SA, for renovation and modernization, new technology purchase, new hall and production line building and people capital.

These restructuring processes and previous production experience allowed the company to become successful in designing and producing rail transport. 